\title{
TÉRI TÁJÉKOZÓDÁSI ZAVAROK SZEREPE A PÁNIK ÉS AZ AGORAFÓBIÁS ÁLLAPOTOK FENNTARTÁSÁBAN*
}

\author{
KÁLLAI JÁNOS-BICSÁK ÉVA-KOLLER ERZSÉBET \\ Pécsi Tudományegyetem, Pszichológiai Intézet \\ E-mail: jkallai@btk.jpte.hu; bicsake@hotmail.com; ekoller@freemail.hu
}

\section{KARÁDI KÁZMÉR}

Pécsi Tudományegyetem, Magatartástudományi Intézet

E-mail:kazmer@cortex.pote.hu

\begin{abstract}
Tizenöt pánikbeteg agorafóbiával, tizenöt generalizált szorongó és tizenöt kontrollszemély téri tanulási és emlékezeti teljesítményét vizsgáltuk valós labirintustájékozódási, valamint komputer által létrehozott virtuális téri tájékozódási feladatban. Eredményeink szerint a pániktól és agorafóbiától szenvedö személyek a generalizált szorongókhoz és a kontrollszemélyekhez viszonyítva labirintusséta által kiváltott stresszhelyzetet követöen gyengébb teljesitményt mutattak téri tanulási feladatokban. A labirintusban való tájékozódási feladatot követöen a pániktól és agorafóbiától szenvedö betegek gyakrabban vétették el a laboratóriumból kivezetó útvonalat, és pontatlan térképet rajzoltak a bejárt labirintus szerkezetéröl. Nem használták hatékonyan az allocentrikus referenciákhoz kötődö disztális tájékozódási pontokat. Ugyanakkor a labirintus stressze után a virtuális téri tájékozódási feladatban is rosszabbul teljesitettek, annak ellenére, hogy a labirintus bejárása elött végzett vizsgálatban nem mutatkozott különbség a csoportok között. Az eredményeket a Figyelemáthelyezés-, valamint a Stressz indukálta felidézés modell alapján értelmeztük.
\end{abstract}

Kulcsszavak: kognitív térkép, téri zavarok, pánik, agorafóbia, jelzöinger-felhasználás

\footnotetext{
A tanulmány az OTKA T-026 558 támogatásával készült.
} 
A pánik és az agorafóbia más szorongásos betegségekkel, valamint a depresszióval való együttjárását számos tanulmány bizonyítja (BARLOW, 1988; LECKMAN és munkatársai, 1983). A pánik és agorafóbiás zavaroknak azonban a komorbiditás ellenére önálló etiológiája van. A komorbiditás vonatkozásában a DSM-IV diagnosztikai rendszer pontosan meghatározza a pánikbetegség agorafóbiával diagnózis specifikumait. Egyes vélemények szerint az újdonsággal kapcsolatos, etológiai forrásból származó félelem (amely együtt jár nyílt tereken, idegen helyeken átélt félelmekkel, gyors vegetatív változásokkal, lassú habituációs rátával) biológiailag meghatározott alapját adja a pánikbetegség agorafóbiával (PA) szindrómának (Kopp, Gruzelier, 1989; Nesse, 1987; MARKs, 1987; Roth, Telech, 1986; KAGAN és munkatársai, 1990).

Klinikai megfigyelések mutatják, hogy in vivo deszenzitizáció során a PA személyek nem tudnak megfelelő figyelmet fordítani a környezetükben zajló eseményekre (WATTS és munkatársai, 1986). Nemcsak viselkedés, de kognitív szinten is elkerülő stratégiát (cognitive avoidance) használnak (FOA, KOZAK, 1986), melyek inadaptív figyelmi beállítódást tartanak fenn, és ezzel konzerválják a környezettel kapcsolatos kognitív zavarokat. Stressz közben ezek a személyek nem tudják fenntartani emlékezési folyamataik téri és idői egységét, elveszítik a kontrollt az aktuális emocionális állapotaik téri és idői kontextusba helyezése felett (JACOBS, NADEL, 1985, 1999a).

WATTS (1986) volt az első, aki klinikai példán, valamint kísérleti helyzetben egyaránt bemutatta a PA személyek egyik sajátos kognitív organizációs zavarát, amelyet napjainkban pánik és agorafóbiás szimptómához kötött téri tájékozódási zavar néven említünk (KÁLLAI és munkatársai, 1995, 1999; JACOB és munkatársai, 1997). Ennek a specifikus kognitív alapzavarnak az a lényege, hogy a személy a tünetek téves értelmezése során (CLARK, 1986), mintegy következményként, fixált egocentrikus pólusú figyelmi stratégiát alakít ki, aminek eredményeként az automatikus figyelmi folyamat az allocentrikus referenciákra nem tud átváltani. Ha az átváltás mégis megtörténik, az allocentrikus információk közül a veszélyszignálokkal kapcsolatban szelektív beállítódás alakul ki (MCNALly, 1996; MATHEwS, MACKINTOSH, 1998; MACLEOD, RUTHERFORD, 1992), ugyanakkor a hatékony tanulást és tájékozódást szolgáló forrásinformációk (idői-téri kontextus) kimaradnak a feldolgozás menetéből (NADEL, JACOBS, 1996; KÁLlAi és munkatársai, 1999). Következményként a tudatosan irányított, kontrollált figyelem lehetősége nagymértékben beszűkül, helyébe egy olyan figyelmi beállítódás lép, amely automatikusan a félelemmel kapcsolatos jelzéseket helyezi előterébe (HIBBERT, 1984; NUNN és munkatársai, 1984; MCNALLY, 1990).

A proximális (egocentrikus referenciákhoz kötött) és a disztális (allocentrikus referenciára épülő) információk felhasználásában megbomlott egyensúly azonban nem tekinthető csupán az egocentrikus fixáció melléktermékének. Terápiás tapasztalataink azt mutatják, hogy a disztális és proximális információs keret használatában megjelenő zavarok a PA kognitív zavarának lényeges mozzanatát mutatják (KÁlLAI, MOLNÁR, 1991). 
JACOBS és NADEL (1999b) leír egy modellt, amely alkalmas az emocionális memória múködési mechanizmusának demonstrálására. Megközelítésükben az emlékek elsajátítása és kioltása két elkülönült, de egészséges személynél szorosan egymásra épülő tanulási rendszerre épít. A „taxon” elvek szerint működő tanulási rendszer ősi tanulási forma, amely a gyermek születésétől fogva folyamatosan fejlődik, modalitástól és kontextustól független kategorizációval rendezi az információkat. A második a „local” elvek szerint működő tanulási rendszer, funkcióképességét kétéves kor körül éri el. Idői és téri szekvenciákba rendezi az információkat, a tanulás eredményét allocentikus és egocentrikus referenciákhoz köti, és részt vesz a kognitív térkép megszerkesztésében (O’KEEFE, NADEL, 1978). Később érő funkciói révén a „local” rendszer működése stressz, intenzív szorongás, szélsőséges hormonális (elsősorban kortikoszteroid) rohamok következményeként instabillá válik (METCALFE, JaCOBS, 1996, 1999). Ez az instabilitás különösen a pánik és agorafóbiás személyek emlékezeti teljesítményében okoz szembeszökő zavarokat (JACOBS, NADEL, 1985, 1999b). Kontrollált valós élethelyzetben végzett tanulási kísérleteinkben magunk is regisztráltunk az említett csoportban téri emlékezési zavarokat (KÁLLAI és munkatársai, 1995, 1999).

Jelen tanulmány célja a pánikbetegség agorafóbiával szindrómában szenvedő, generalizált szorongó és egészséges kontrollszemélyek téri emlékezési teljesítményének összehasonlító vizsgálata. A téri tanulás vizsgálóeszköze egy potenciálisan félelmet mobilizáló alagsori útvesztő, továbbá a labirintus bejárása előtt és után teljesített, komputer által létrehozott virtuális térben végzett helytanulási feladat. Több tanulmány foglalkozott már a reális körülmények között végzett helytanulás vizsgálatával (SiEgEL, WHITE, 1975; CORNELl és munkatársai, 1989; HiRTLE, HUDSON, 1991; GLASSMAN és munkatársai, 1994; LAWTON, 1996; OvERMAN és munkatársai, 1996; DABBS és munkatársai, 1998) vagy a komputer által létrehozott virtuális térben végzett tanulás eredményeinek elemzésével (JACOBS és munkatársai, 1997, 1998; ASTUR és munkatársai, 1998; SANDSTROM és munkatársai, 1998). Jelen vizsgálatban mindkettő együtt szerepel.

Személyek: A PA személyek kétharmad része nő, ugyanakkor a férfiak és nők között a téri tanulásban robusztus teljesítménykülönbségek vannak (NOYES, HOEHMSARIC, 1998; SANDSTROM és munkatársai, 1998). Mindezekre tekintettel csak nőket kértünk fel vizsgálatban való részvételre. A páciensek független pszichiáter team DSM-IV diagnózisa után, várólistáról lettek behívva. 2 hetes pszichoaktív gyógyszerektől mentes időszakot követően vettek részt a vizsgálatban. Szorongás miatt kialakult gyógyszeraddikciótól szenvedő személyeket nem vontunk be a vizsgálatba. Valamennyi páciens betegséganamnézise meghaladta az 1 éves időtartamot. 15 pánikbeteg agorafóbiával (átlagéletkor: 32,9; SD: 9,7), 15 generalizált szorongó (GS; átlagéletkor: 31,47; SD: 4,8) és 15 kontrollszemély (átlagéletkor: 34,7; SD: 9,4). Az 1. táblázat mutatja a minta összesített diagnosztikai jellemzőit. A kontrollszemélyek gyógyszert nem szedtek, kardiovaszkuláris vagy egyéb krónikus betegségben nem szenvedtek. A vizsgálatban részt vevő személyek a Regionális Orvosi Etikai Bizottság által jóváhagyott tájékoztatásban részesültek, és aláírták a vizsgálat lebonyolításához szükséges együttmüködési nyilatkozatot. 
1. táblázat. A minta diagnosztikai jellegzetességei: 1. Pánikbetegség agorafóbiával (PA), 2. Generalizált szorongás (GS), 3. Kontrollcsoport (K)

\begin{tabular}{|c|c|c|c|c|c|}
\hline Mutató & Csoportok & Átlag & SD & F-érték & Szignifikancia \\
\hline Életkor & $\begin{array}{l}\text { 1. } \mathrm{PA} \\
\text { 2. } \mathrm{GS} \\
\text { 3. } \mathrm{K} \\
\end{array}$ & $\begin{array}{l}32,93 \\
31,47 \\
34,7\end{array}$ & $\begin{array}{l}9,7 \\
4,8 \\
9,4\end{array}$ & $\mathrm{~F}=0,392$ & n.s \\
\hline Iskolázottság & $\begin{array}{ll}\text { 1. } \mathrm{PA} \\
\text { 2. } \mathrm{GS} \\
\text { 3. } \mathrm{K} \\
\end{array}$ & $\begin{array}{l}1,93 \\
1,93 \\
1,93 \\
\end{array}$ & $\begin{array}{l}0,59 \\
0,59 \\
0,59 \\
\end{array}$ & $\mathrm{~F}=0,000$ & n.s \\
\hline Pánik & $\begin{array}{ll}\text { 1. } \mathrm{PA} \\
\text { 2. } \mathrm{GS} \\
\text { 3. } \mathrm{K} \\
\end{array}$ & $\begin{array}{l}57,26 \\
39,00 \\
24,93 \\
\end{array}$ & $\begin{array}{r}19,83 \\
16,30 \\
4,77 \\
\end{array}$ & $\mathrm{~F}=17,339$ & $\begin{array}{c}\mathbf{P}<\mathbf{0 , 0 0 1} \\
2-3^{*}, 1-2^{*}, 1-3^{*}\end{array}$ \\
\hline Agorafóbia & $\begin{array}{ll}\text { 1. } \mathrm{PA} \\
\text { 2. } \mathrm{GS} \\
\text { 3. } \mathrm{K} \\
\end{array}$ & $\begin{array}{c}31,2 \\
12,4 \\
9,86 \\
\end{array}$ & $\begin{array}{l}6,63 \\
6,51 \\
5,69 \\
\end{array}$ & $\mathrm{~F}=51,431$ & $\begin{array}{c}\mathbf{P}<\mathbf{0 , 0 0 1} \\
2-3^{*}, 1-2,{ }^{*} 1-3^{*}\end{array}$ \\
\hline Szociális félelem & $\begin{array}{ll}\text { 1. } \mathrm{PA} \\
\text { 2. } \mathrm{GS} \\
\text { 3. } \mathrm{K} \\
\end{array}$ & $\begin{array}{l}22,13 \\
19,13 \\
17,73 \\
\end{array}$ & $\begin{array}{l}7,65 \\
8,05 \\
7,53 \\
\end{array}$ & $\mathrm{~F}=1,262$ & n.s. \\
\hline $\begin{array}{l}\text { Állattól való féle- } \\
\text { lem }\end{array}$ & $\begin{array}{ll}\text { 1. } \mathrm{PA} \\
\text { 2. } \mathrm{GS} \\
\text { 3. } \mathrm{K} \\
\end{array}$ & $\begin{array}{l}9,00 \\
7,93 \\
7,80 \\
\end{array}$ & $\begin{array}{l}6,86 \\
6,22 \\
4,19 \\
\end{array}$ & $F=0,188$ & n.s. \\
\hline $\begin{array}{l}\text { Szex látványától } \\
\text { való félelem }\end{array}$ & $\begin{array}{ll}\text { 1. } & \mathrm{PA} \\
\text { 2. } & \mathrm{GS} \\
\text { 3. } & \mathrm{K} \\
\end{array}$ & $\begin{array}{l}8,06 \\
7,86 \\
7,20 \\
\end{array}$ & $\begin{array}{l}4,31 \\
4,53 \\
3,87 \\
\end{array}$ & $\mathrm{~F}=0,171$ & n.s. \\
\hline $\begin{array}{l}\text { Betegségtől való } \\
\text { félelem }\end{array}$ & $\begin{array}{ll}\text { 1. } & \mathrm{PA} \\
\text { 2. } & \mathrm{GS} \\
\text { 3. } \mathrm{K} & \end{array}$ & $\begin{array}{l}19,66 \\
11,73 \\
11,72\end{array}$ & $\begin{array}{l}7,48 \\
9,85 \\
6,76 \\
\end{array}$ & $\mathrm{~F}=4,742$ & $\begin{array}{l}\mathbf{P}<\mathbf{0 , 0 1} \\
1-2^{*}, 1-3^{*}\end{array}$ \\
\hline Szorongásosság & $\begin{array}{ll}\text { 1. } \mathrm{PA} \\
\text { 2. } \mathrm{GS} \\
\text { 3. } \mathrm{K}\end{array}$ & $\begin{array}{l}58,66 \\
39,93 \\
21,32\end{array}$ & $\begin{array}{l}2,4 \\
8,93 \\
8,98 \\
\end{array}$ & $\mathrm{~F}=15,46$ & $\begin{array}{l}\mathbf{P}<\mathbf{0 , 0 0 1} \\
1-3^{*}, 2-3^{*}\end{array}$ \\
\hline Depresszió & $\begin{array}{l}\text { 1. } \mathrm{PA} \\
\text { 2. } \mathrm{GS} \\
\text { 3. } \mathrm{K}\end{array}$ & $\begin{array}{r}17,13 \\
18,06 \\
7,73\end{array}$ & $\begin{array}{r}11,26 \\
8,05 \\
4,92\end{array}$ & $F=6,802$ & $\begin{array}{c}\mathbf{P}<\mathbf{0 , 0 1} \\
2-3^{*}, 1-3^{*}\end{array}$ \\
\hline
\end{tabular}

* Tukey Post Hoc Teszt szignifikáns a jelzett csoportokban (1, 2 vagy 3).

TÉRI TÁJÉKOZÓDÁS MÉRÉSE

KOMPUTER ÁLTAL LÉTREHOZOTT VIRTUÁLIS TÉRBEN

A vizsgálat eszköze a JACOBS és munkatársai (1997) által kifejlesztett Aréna-feladat (Computer-Generated Arena Task CGArena, részletes leírását lásd az arizonai szorongáskutató csoport honlapján. A CGArena software letölthető: http:// w3. arizona.edu/ arg). A feladat két részből áll, az első részben a személy az aré- 
nában a joystickkel való tájékozódás lehetőségeit gyakorolja. A kör alakú fallal körülvett aréna padlózatán kis felületű, helyzetét nem változtató, környezetétől vizuálisan jól elkülönülő szőnyeg van elhelyezve. Az egyszerű gyakorló feladat lényege, hogy az előre, oldalra és a körbeforgás lehetőségét is biztosító joystick segítségével rá kell állni erre a szőnyegre. A szőnyegen tartózkodás időszakában folyamatos ritmusos elnyújtott kopogó hang hallható. A helyzettel való ismerkedést követően a tesztszakaszban szereplő helytanulási feladat a következő: A szőnyeg ebben a szakaszban nem látható, próba szerencse módon kell megtalálni. Mikor megtalálta, a kopogó hanggal együtt megjelenik a szőnyeg is. A szőnyegen tartózkodva a személynek körbeforogva meg kell jegyeznie az aréna külső falán látható azonosítási pontok, képek egymáshoz viszonyított helyzetét, hogy a következő próbák során a próba szerencse stratégiát feladva minél hamarabb megtalálja a rejtett szőnyeg helyét. A közvetlen on-line adatrögzítés lehetővé teszi a rejtett szőnyeg megtalálása próbáról próbára változó latenciájának mérését. Minél kisebb a felderítési latencia, annál hatékonyabb a személy allocetrikus szignálokra épülő helytanulási teljesítménye. A CGArena feladatból a navigációs szignálok módosítasával egy CGArena A és egy CGArena B változatot hoztunk létre, amelyeket a labirintussétát megelőzően és a sétát követően random sorrendben használtunk fel.

Labirintusséta: Egy labirintusból a kivezető utat megtalálni az ember ősi kihívásaihoz tartozik. A kijárat megtalálása a megnyugvást hozza. Különösen igaz ez az utcákon, bevásárló központok útvesztőiben, metróalagutakban szorongva bolyongó agorafóbiától szenvedő személyekre. A vizsgálat helyszínét jelentő klinika alagsori folyosórendszere spontán lehetőséget kínált a tájékozódási képesség reális élethelyzetben való tesztelésére. Az útelágazássokkal, zsákutcákkal telített komplexum 142 m hosszú. A folyosórendszer (labirintus) alaprajza a 1. ábrán látható. Az ábra a folyosó belső falain elhelyezett 11 navigációs objektum helyét is tartalmazza.

\section{ELJÁRÁS}

I. szakasz: A személyek a CGArena feladattal kapcsolatos joystickhasználati tapasztalat megszerzése, a látható szőnyeggel kapcsolatos gyakorlatok után 8 egymást követő próbában, próbánként 3 perc időtartamig explorálhatták az arénát. Az eredményes felderítés után közvetlenül áttérhettek a következő próbára. A vizsgálatot a labirintussétát követően újra megismételtük. Amennyiben a személy a CGArena A verzióval kezdte a vizsgálatot, a labirintussétát a CGArena B feladat követte, vagy megfordítva.

II. szakasz: Labirintus spontán rögzítése. A reális labirintus bejáratánál a következő instrukció hangzott el: „Most át kell mennünk az alagsoron a kísérleti helyiséghez.” Ezt követően a vizsgálatvezető asszisztens további instrukció nélkül átvezette a személyt a labirintuson a labirintus végénél lévő helyiségig. 


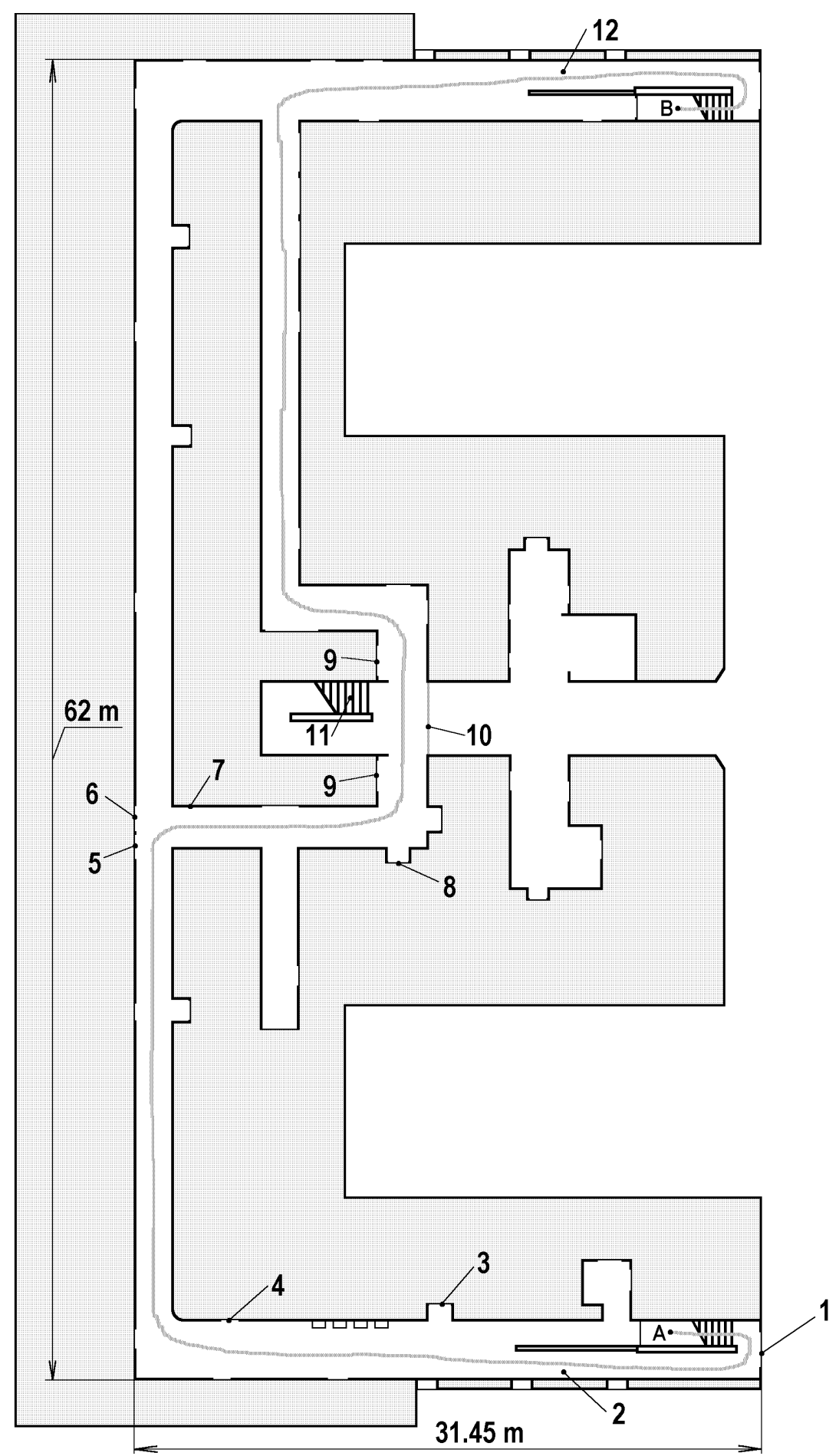


III. szakasz: Labirintusséta. Amint a személy megérkezett a labirintus kijáratához, a következő instrukció hangzott el: „Az imént jöttünk át a labirintuson. Megkérem, ugyanazt az utat használva, amelyen idefelé jöttünk, menjen vissza a kiindulási pontunkhoz. Az utat egyedül kell megtennie, segítségre nem számíthat.” A személyt egy asszisztens követte 5 méter távolságból, és videóra vette a személy útját. Az asszisztens még gesztusaiban sem adhatott segítséget, csak akkor léphetett közbe, ha a vizsgálatot lehetetlenné tevő pánikállapot alakult ki, vagy ha a személy eltévedt és 10 méternél hosszabb tévutat tett már meg. Egy szakember a vizsgálat teljes időtartamában elérhető közelségben tartózkodott. Pánikroham miatt egyik vizsgálatot sem kellett megszakítani.

IV. szakasz: Interjú. A korábbi vizsgálati szakasztól független asszisztens a labirintusséta után kikérdezte a személyt a tapasztalatairól. Megkérte, idézze fel, hogy a labirintusséta során milyen eszközök segítségével tájékozódott, majd arra kérte, hogy egy standard A/4-es nagyságú lapra rajzolja le a visszafelé vezető útvonal térképét. Ezt követően mind a személy, mind a személy kalauza, egymástól független 0-4 fokú, egyáltalán nem éreztem szorongást-nagyon szorongtam pólusú skálán értékelte a személy szorongásának mértékét a labirintusséta közben.

V. szakasz: A labirintusséta utáni CGArena vizsgálat. Az első vizsgálattal megegyező feltételek között zajlott le. A CGArena A és a CGArena B vizsgálat között $40( \pm 5)$ perc telt el.

VI. szakasz: A kérdőívek kitöltése. Valamennyi személy kitöltött egy tesztcsomagot, amely az alábbi kérdőíveket tartalmazta: Beck depresszió kérdőív (BDI) (BECK, 1978; KOPP, FORIS, 1995), Spielberger Trait szorongás kérdőív (TraitAI) (SPIELBERGER és munkatársai, 1970; SIPOS, 1978), Félelemfelmérő lista (Fear Survey Schedule (FSS) (ARRINDELL, 1993), amely tartalmazta az alábbi faktorokat: agorafóbia (AGF), szociális félelem (SOF), állatoktól való félelem, (ANF), szexuális és agresszív tartalmú jelenetektől való félelem (SF), betegségtől, haláltól, sérüléstől való félelem (IF), valamint egy pániktünetlistát (Panic List, PI; GORMAN, 1987).

\section{AZ ADATOK ÖSSZEÁLLÍTÁSA}

Labirintusséta: Az adatgyűjtés a labirintusséta közben készült videofelvételre, valamint a sétát követő interjú rögzített hanganyagára támaszkodik. A téri tájékozódás tekintetében három különböző téri tanulási funkciót pontoztunk: navigációs pontok száma, úttalálási pontosság, térképrajzolási pontosság.

\footnotetext{
1. ábra. A labirintusséta színhelye, az alagsori folyosórendszer alaprajza a tájékoztató jelzések helyének feltüntetésével: $A$ ) a visszafelé vezető út indulási helye; $B$ ) a labirintus kijárata. 1 . kertkapu, 2. kerti ablakok, 3. étterem bejárata, 4. mosdók, 5. „Gondnoki Iroda” felirat, 6. MRI vizsgáló folyosóajtaja, 7. természeti kép a falon, 8. „Neuroscience Classroom” felirat az ajtón, 9. liftajtó, 10. „Vészkijárat” felirat, 11. felfelé vezető lépcső, 12. hủtőkamra
} 
Navigációs pontok száma (navigáció): Az interjúban elhangzott navigációs tárgyak számszerü összege.

Úttalálási pontosság (úttalálás): A személy útvonalát összevetettük az alagsor alaprajzán szereplő valós útvonallal. Amennyiben a személy eltért attól, az eltérés nagyságát levontuk a teljes útvonal hosszából. A hibátlan útvonal-teljesítés 100\%os teljesítmény. Az eltévedés során megtett útvonal százalékban kifejezett értékét levontuk a 100\%-ból. Az így kapott érték fejezte ki az úttalálás pontosságát. Az alacsony értékek jelzik a pontatlan útvonalkövetést.

Térképrajzolás (térkép): Az A/4-es lapra megrajzolt térkép tartalmát három adatcsoportra bontottuk, melyekből z-transzformációt követően a standardizálási eljárás után közös, a térképrajzolás pontosságát kifejező összesített pontszámot hoztunk létre. A térképpontszám tartalma: $a$ ) az első hibásan megrajzolt fordulóig megrajzolt fordulók száma, $b$ ) az első hibás fordulóig megrajzolt útszakasz hosszúságát a valós alaprajzhoz viszonyítottuk, és százalékban fejeztük ki a teljes és a megrajzolt útvonal közti különbséget, melynek a reciproka adta a megrajzolt térképszakasz pontatlansági pontszámát. Az alacsony értékek jelzik a pontatlanság mértékét, $c$ ) a labirintus alaprajzát standard mintának tekintve a személy térképén levő rajz induló- és végpontjának egymástól való távolságát figyelembe véve meghatároztuk a személy által készített térkép méretarányát, tehát hogy a valóságos indulási és érkezési pontok közötti távolságnak hányad része a személy által rajzolt térképen található induló és érkezési pontok távolsága. Ennek alapján kiszámítottuk a személy térképének méretarányát, majd a fordulók közötti szakaszok hosszúságát szakaszról szakaszra, az első tévesen berajzolt fordulópontig, arányában összehasonlítottuk az eredetivel. A standardtól való eltérés nagyságának abszolút értéke alapján határoztuk meg a térkép elemeinek a valós útvesztőben szereplő távolságokhoz való viszonyát. Az arányossági, a fordulási és a hosszúsági pontszámok összege alapján közös pontszámban határoztuk meg, hogy a személy által megrajzolt térkép mennyiben követte a valóságost.

CGArena: Mind a CGAréna A, mind a CGAréna B esetén próbánként meghatároztuk a rejtett platform megtalálásának a latenciáját. Azt követően a hét próbában mutatott latenciaidőt összevonva megkaptuk a rejtett platform felderítésére fordított, személyre jellemző átlagos időtartamot. A rendelkezésre álló CGAréna A és CGAréna B platformfelderítési latenciaidők alapján az alkalmazás random sorrendje ismeretében azonosítottuk a labirintusséta előtti (preCGA) és a labirintussétát követő (postCGA) CGAréna rejtett platform helyének megtanulását kifejező pontszámot. Minél alacsonyabb a pontszám, annál hatékonyabb a tanulás.

\section{EREDMÉNYEK}

A minta diagnosztikai jellemzői: Összehasonlítva a PA, GS és a K csoport eredményeit pánikszimptómák gyakorisága tekintetében, az ANOVA teszt a várt különbséget jelzi a csoportok között $(\mathrm{F}(2,42)=17,339 \mathrm{p}<0,001)$. Hasonló különbség mutatkozik az agorafóbiás tünetek $(\mathrm{F}(2,42)=51,431 \mathrm{p}<0,001)$, betegségtől való félelem $\mathrm{F}(2,42)=4,742 \mathrm{p}<0,01)$, szorongásosság $(\mathrm{F}(2,42)=15,46 \mathrm{p}<0,001)$, vala- 
mint depresszió $(\mathrm{F}(2,42)=6,802 \mathrm{p}<0,01)$ tekintetében. A Tukey post-hoc teszt mutatja, hogy a PA személyek magasabb pánik, agorafóbia és betegségtől való félelemértékekkel rendelkeznek, mint a GS vagy a K csoport. Továbbá a PA és GA csoportok nagyobb depresszió és szorongásossági értékekkel rendelkeznek, mint a $\mathrm{K}$ csoport, de e tekintetben a PA és a GS csoport értékei között nincs lényeges különbség (lásd 1. táblázat).

A térképrajzolás pontosságát kifejező térképváltozó validitása: A térképrajzolás pontosságát kifejező három különböző pontérték, a fordulópontok száma, a helyesen megrajzolt útszakasz hossza, valamint az arányossági pontszám interkorrelációja, mutatja a térképváltozó konvergens validitását. Magas korreláció mutatkozik a térképérték, valamint az arányosság $(\mathrm{r}(43)=0,604, \mathrm{p}<0,001)$, a hosszúság $(\mathrm{r}(43)$ $=0,920, \mathrm{p}<0,001)$, valamint a fordulópontok száma $(\mathrm{r}(43)=0,911, \mathrm{p}<0,001)$ értékek között. Ugyanakkor a térképváltozó korrelációt mutat a navigációértékekkel $(\mathrm{r}(43)=0,546, \mathrm{p}<0,001)$, de nem korrelál az úttalálási értékkel $(\mathrm{r}(43)=0,213$ n.sz.). Ezek a kapcsolatok mutatják, hogy a térképváltozó értékei konzisztensek, de a téri funkciók tekintetében önálló mérőértékkel rendelkeznek.

Hipotézisünk szerint a labirintusséta jelentős szorongást indukál a PA, kisebb mértéküt a GS és jelentéktelen intenzitásút a K csoportban. A feltételezéssel összhangban az ANOVA-összehasonlítás mutatja, hogy a személyt követő vizsgálatvezető által megítélt szorongás szintje mind a három csoportban különböző $(\mathrm{F}(2,42)=29,288, \mathrm{p}<0,001)$. Tukey post-hoc teszt mutatta, hogy a labirintusséta időszakában a kontrollhoz képest a PA személyek voltak a legszorongóbbak, majd a GS személyek következtek, azt követően pedig a kontrollszemélyek. A személyek önmaguk szorongásszintjéről adott beszámolói alapján végzett ANOVA-analízis szignifikáns különbséget mutatott a csoportok között, $\mathrm{F}(2,42)=3,525, \mathrm{p}<0,05$. Tukey post-hoc teszt szerint a különbség szignifikáns PA és C csoport között, de nem szignifikáns GS és a kontrollcsoport között.

Megállapíthatjuk, hogy az adatok többsége arra utal, hogy a labirintusséta jelentős szorongást indukált a PA-csoportban, közepes mértékűt a GS- és enyhe mértéküt a kontrollcsoportban.

2. táblázat. Téri tanulás és emlékezet a labirintusséta közben

\begin{tabular}{|l|c|c|c|c|c|}
\hline \multicolumn{1}{|c|}{ Feladat } & Csoportok & Átlag & SD & F-érték & Szignifikancia \\
\hline Térképrajzolás & 1. PA & $-0,31$ & 0,60 & $\mathrm{~F}=3,055$ & $\mathbf{p}<\mathbf{0 , 0 5}$ \\
& 2. GS & 0,40 & 0,87 & & \\
& 3. K & $-0,08$ & 0,81 & & $2-3^{*}$, \\
\hline \multirow{2}{*}{ Navigációs pont } & 1. PA & 3,8 & 1,32 & $\mathrm{~F}=1,378$ & \\
& 2. GS & 4,8 & 2,11 & & n.s. \\
& 3. K & 4,4 & 1,51 & & \\
\hline Úttalálás & 1. PA & 88,09 & 7,83 & $\mathrm{~F}=11,117$ & $\mathbf{p}<\mathbf{0 , 0 0 1}$ \\
& 2. GS & 89,04 & 5,44 & & $2-3^{*}, 1-3^{*}$, \\
& 3. K & 96,81 & 5,47 & & $1-2^{*}$ \\
\hline
\end{tabular}

* Tuckey post-hoc teszt különbségek az 1., 2., 3. csoportok között. 
Helytanulás és -felidézés, „valós” térben: A következő lépésben a téri tanulás és a memóriafunkciók csoportkülönbségeit elemeztük a labirintussétával összefüggő teljesítmények alapján. (A 2. táblázat tartalmazza az eredményeket.)

Az ANOVA-statisztika mutatta, hogy a térképrajzolás pontossága tekintetében különbség van a csoportok között $(\mathrm{F}(2,42)=3,055, \mathrm{p}<0,05)$. Tukey post-hoc teszt szerint a GS személyek pontosabb térképet rajzolnak, mint a K személyek, de a PA és a GS csoport térképrajzolási pontossága számottevően nem különbözik egymástól.

Navigációs szignálok száma tekintetében ANOVA nem mutat lényeges különbséget a csoportok között $(\mathrm{F}(2,42)=1,378)$.

Az úttalálás tekintetében jelentős különbség van $(\mathrm{F}(2,42)=11,117, \mathrm{p}<0,001)$. post-hoc Tukey-teszt szerint a kontroll volt a legpontosabb, majd a GS és a PA mutatta a legrosszabb úttalálási teljesítményt. Az eredmények azt mutatják, hogy a PA csoport a kivezető út megtalálásában rosszabbul teljesít, mint a GS csoport, annak ellenére, hogy szorongásossági szintjük között nincs számottevő különbség. A szorongás aktuális szintje közti különbség azonban mutatja, hogy a labirintus stresszspecifikus a PA személyek felidézési és tanulási funkciója szempontjából. Ugyanakkor láttuk, hogy a navigációs pontok számának felidézésében csoportspecifikus különbségek nem jelennek meg. A térkép megrajzolása tekintetében a GS személyek jeleskednek, a PA csoportnál jobb teljesítményt nyújtanak.

Helytanulás „virtuális” térben, CGAréna teljesítmények: A platform megtalálásának latenciaidejét megmértük a csoportspecifikus szorongásmobilizáló labirintusséta előtt, majd a labirintusa után. (Az eredményeket a 2. ábra mutatja.)

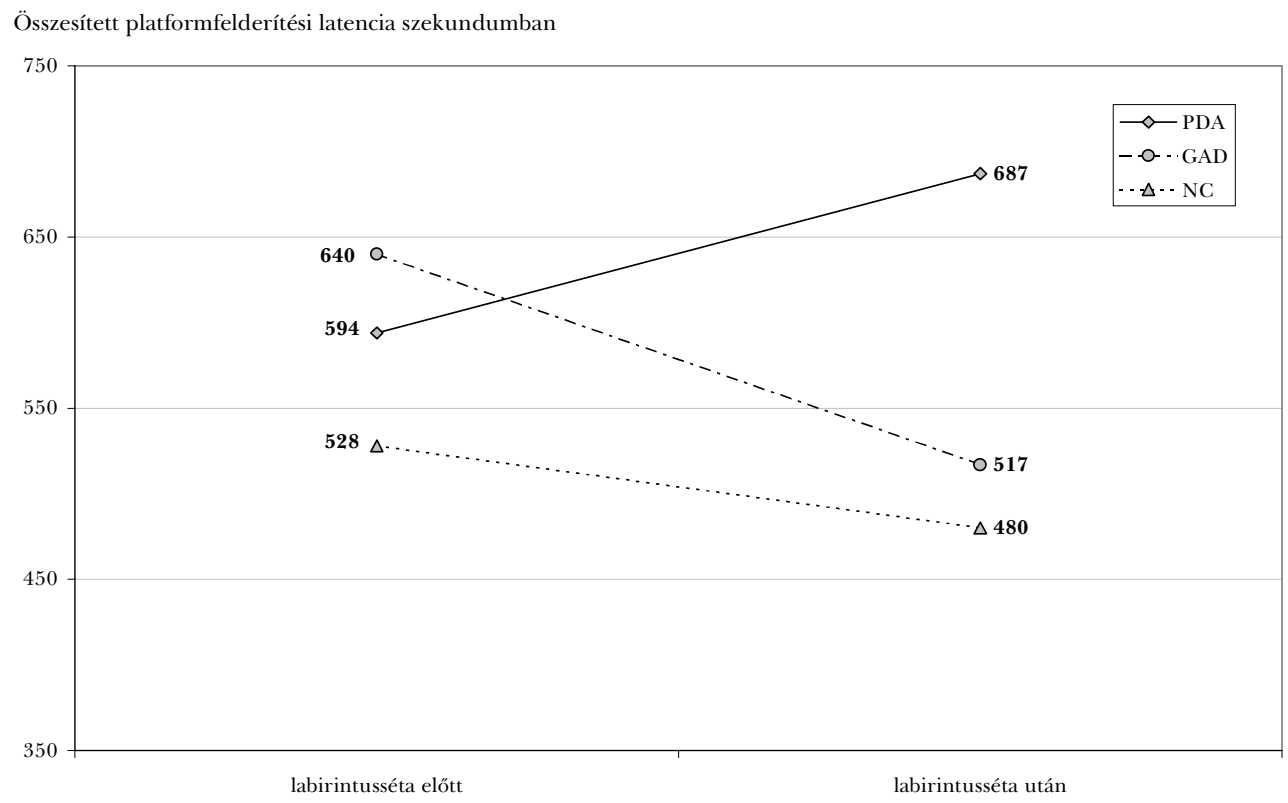

2. ábra. Helytanulás virtuális térben 
Az preCGAréna és a postCGAréna között végzett ANOVA eredménye szerint a csoportok között nem volt különbség a labirintusséta elött végzett CGAréna tanulási teljesítményben, $\mathrm{F}(2,42)=1,263$, de a labirintusséta után, a csoportok között a rejtett platformfelderítési idő latenciája tekintetében lényeges különbség mutatkozott, $\mathrm{F}(2,42)=3,514, \mathrm{p}<0,05$. A post-hoc Tukey-teszt megmutatta: annak ellenére, hogy a labirintusséta előtt nem volt a virtuális aréna feladatban különbség a PA, GS és C csoportok helytanulási képességében, a labirintussétát követően a kontrollcsoporthoz viszonyítva jelentősen romlott a PA személyek helytanulási teljesítménye. Úgy tűnik, a labirintusstressz visszavetette a PA személyek téri tanulási képességét, de ugyanakkor ilyen hatás a GS- és a kontrollcsoportban nem mutatkozott.

\section{MEGVITATÁS}

Adataink mutatják, hogy a labirintusséta jelentős szorongást indukált PA, kisebb mértékűt GS és nem számottevő mértéküt a kontrollszemélyek esetében. PA személyeknél a labirintusséta által kiváltott magasabb szintű szorongás rontja az úttalálási teljesítményt, a térképkonstrukciót, és ugyanakkor visszaveti a szorongást mobilizáló szituációt követő virtuális téri tanulási feladatban a téri szignálok hatékony használatát. Adataink határozottan mutatták, hogy a labirintussétát követően a pánik és agorafóbiás személyek, annak ellenére, hogy a szorongást provokáló helyzetet megelőzőleg ilyen jellegű zavarokat nem mutattak, nem tudták hatékonyan felderíteni a virtuális térben elhelyezett rejtett platformot. Más csoportokhoz képest a tájékozódásban alig tudták a tájékozódás során felhasználni az allocentrikus helyzetű szignálokat.

$\mathrm{Az}$ adatok értelmezésében két alternatív lehetőséget mutatunk be. Az egyik tradicionális kognitív, figyelemszabályozási modell (attention allocation model; EASTERBROOK, 1959). A második az idegtudományok területéről származó többszörös emlékezeti raktározás modellre támaszkodik (JACOBS, NADEL, 1985). EASTERBROOK (1959) szerint a környezeti ingerek felhasználása (cue utilization) a szorongás növekedésével beszűkül. Az elképzelés kísérleti demonstrációja a jól ismert „weapon effect”-kísérlet, amely mutatja, hogy szorongást provokáló helyzetben a veszélyszignált hordozó mentális elem percepciója kiszorítja a perceptuális mezőből a környezet más fontos jelzőingereit, dekontextualizálja a szituációt (LOFTUs, E. F., LOFTUs, G., R. Messo, 1987; MAAss, KrohnKen, 1989), melynek következményeként az emlékezeti rögzítés helyhez nem kötött fragmentumokban történik (VAN DER KOLK, FISLER, 1995).

A jelzőinger felhasználásának ezt a sajátos formáját számos metafora teszi érzékletessé: perceptuális csatorna beszűkülése, centrális jellegzetességekre való beszűkülés, válaszhierarchia-változás és így tovább (EASTERBROOK, 1959). Adatainkat figyelembe véve Easterbrook hipotézise ráirányítja a figyelmet a PA személyek jelzőinger-használati hiányosságaira. A szorongást mobilizáló jelzőingerek a percepcióban kiemelt hangsúlyt kapnak, de ugyanakkor a környezettel kapcsolatos forrásinformációk mennyisége jelentősen csökken, a pánik és agorafóbiás szoron- 
gás dekontextualizálja a szituációt. Ennek következtében a környezettel kapcsolatos információ, illetve kontrollhiány, fokozva a szorongást, tovább szúkíti az adekvát megoldás lehetőségeit.

A figyelemirányítás újabb modellje (Attention Allocation Model; NunN és munkatársai, 1984; WiLliams és munkatársai, 1988; THINUS-BLANC, 1996) részletesebben tárgyalja e jelenséget. A stressz hatása kettős, egyrészt hat a nem automatikus figyelmi folyamatokra (melynek jellemzői: párhuzamos információfeldolgozás, szúk figyelmi kapacitás, automatikus fixáció), másrészt az irányított figyelmi folyamatokra (melynek sajátosságai: szukcesszív feldolgozás, nagyobb tudatos kapacitás, valamint stratégiahasználat). Ezek együttese hozza létre a szituációnak megfelelő figyelmi beállítódást.

E modell PA személyek dinamikájára alkalmazva: magas stressz mellett a környezeti ingerek felhasználását első szakaszban egy automatikus preattentív figyelmi folyamat készíti elő, mely PA személyeknél a negatív tartalmú események megjelenésére koncentrál (threat priming effect). A priminghatás forrása lehet biológiai (gyors hormonális vagy kardiovaszkuláris stresszek) vagy kognitív természetű (téves interpretáció vagy anticipációs szorongás), amelyet egy affektív döntési folyamat követ. A preattentív folyamat második elemeként történik meg a figyelem adott jelzőingerek irányába való kihelyezése (secondary resource allocation; WiLLIAMS és munkatársai, 1988). A jelen tanulmányban szereplő csoportok téri tanulási teljesítményeinek vizsgálata azt mutatja, hogy a preattentív figyelmi folyamatok szabályozásának ebben a második szakaszában keletkezik zavar. A pánikbeteg és agorafóbiás nem a környezetétôl, hanem saját félelmeitől fél (félelmi paradoxon), ezért nem a környezetének, hanem saját vegetatív állapotának kontrolljára törekszik. A figyelem forrása ennek következtében egocentrikus pozícióban marad. Csupán a félelem etológiailag huzalozott forrásai maradnak a figyelem külső fókuszában. Ennek következménye a környezeti ingerek dekontextualizációja.

A fentiek figyelembevételével felhasználhatunk egy másik modellt is, amely a kognitív oldal mellett elősegíti a PA személyek esetén tapasztalt téri tájékozódási zavarok dinamikájának a megértését. JACOBS és NADEL (1985) neurobiológiai elgondolása szerint magas stressz, felfokozott szorongásos állapotok magas kotikoszteroid-aktivitással járnak együtt. A cirkuláló glukokortikoid és mineralokortikoidok a hippocampusban és az amigdalában halmozódó kortikoszteroid receptorokon keresztül jelenősen módosítják a szervezet emocionális állapotát és tanulási (LTP) képességét. A kortikoszteroid mennyisége és a tanulási hatékonyság összefüggése azonban nem lineáris, hanem fordított U összefüggést mutat. Közepes kortikoszteroid hormonszint javítja, magas jelentősen rontja elsősorban a téri tanulás lehetőségeit. Magas kortikoszteroid szint mellett a hippocampus normál működése és a hozzá kapcsolt funkciók - helytanulás, kognitív térkép megszerkesztése, rövid idejű raktározás - jelentős zavart szenvednek (JACOBS, NADEL, 1985, 1999a; Lupien, McEven, 1997; MetCalfe, JaCOBS, 1996, 1998, 1999; NADEL, JACOBS, 1996).

Ez a modell feltételezi, hogy ezek a biokémiai változások nemcsak primingben, de közvetlenül a téri funkciók zavarásában is megmutatkoznak. Megzavarják a helytanulás menetét (JACOBS, NADEL 1999a; MCGAUGH és munkatársai, 1993). PA 
személyeknél feltételezhetjük ezt a folyamatot, de egy közlés előtt álló vizsgálatunk mutatja, hogy a kortizol és aldosteron emelkedett szintje különböző, de jól körülhatárolt formában zavarja meg a téri tanulást. Úgy látjuk, hogy ez a modell a fentiekkel együtt alkalmas a valós és virtuális térben végzett téri tájékozódással kapcsolatos eredményeink diagnosztikai kategóriákra jellemző sajátosságainak megragadására.

Adataink mutatják, hogy a labirintusséta után végzett virtuális téri feladatban a pániktól és agorafóbiától szenvedő személyek téri tanulási teljesítménye más csoportokhoz viszonyítva jelentősen romlott. A szorongást provokáló helyzet után nehezebben találják meg a rejtett platformot.

Eredeti kérdésfeltevésünk szerint különbséget várunk reális és virtuális térben végzett helytanulási feladatokban különböző fajta és különböző szintű szorongástól szenvedő személyek esetén. Láthattuk, hogy PA személyek rosszabbul teljesítenek labirintusban és a stresszt követő virtuális aréna feladatban. Allocentrikus referenciakeretre épített disztális jelzőingereket kevésbé használnak a tájékozódás során, nem tudják hatékonyan mozgósítani a környezetről kialakított mentális térképet sem. Egocentrikus referenciákra való beszűkülésük miatt a szituáció kontextuális jelzőingerei kimaradnak a felidézés menetében. Nem tudnak átváltani az egocentrikus referenciákról az allocentrikusra.

Úgy gondoljuk, hogy a kontextuális információk enkódolásának ez a zavara nem tekinthető csupán az automatikus figyelemből származó merev figyelemfixációs rendellenességnek. A PA személyek vonatkozásában a specifikus figyelmi beállítódásnak a háttérben az ezt az állapotot fenntartó neuropszichológiai zavarok is okai lehetnek. Az intenzív szorongás önmagában is megzavarhatja a hippocampális és a para-hippocampális területek kényes kapcsolatára épülő térképkészítő folyamatokat (METCALFE, JACOBS, 1998, 1999; NADEL, JACOBS, 1996), melynek következménye a PA személyek teljesítményében a valós labirintusfeladatban megmutatkozó téri tanulási zavar.

Adataink konzisztensek a stressz által létrehozott felidézési zavarokat leíró modell által jósolható eredményekkel (stress induced recovery SIR, JACOBS, NADEL, 1985; METCALFE, JACOBS, 1998, 1999), mind e modell alapján kialakított kognitív terápiás gyakorlattal (KÁLLAI, 1989; KÁLLAI és munkatársai, 1999), továbbá a PA személyek kognitív organizációjának sajátosságaival (WATTS és munkatársai, 1986; MACLEOD, RUTHERFORD, 1992; NUNN és munkatársai, 1984; MCNALlY, 1996; MATHEWS, MACKINTOSH, 1998).

Kritikusan meg kell említenünk, hogy eredményeink nemcsak kérdésekre adtak választ, de új válaszra váró kérdéseket is felvetettek. Ezek között továbbra is megválaszolatlan maradt, hogy a magas szorongásszint mellett megjelenő téri tájékozódási zavarra való esékenység mennyiben szűkül le egyetlen diagnosztikai kategóriára. PA személyek vonatkozásában a bizonyított téri zavarra való esékenység megállapítása csak a generalizált szorongástól szenvedőkre és a kontrollszemélyekhez viszonyítva érvényes. Nyitva maradt továbbá az a kérdés is, hogy az említett vulnerabilitás állapot vagy vonás jellegű hatásokra vezethető-e vissza.

Mindezek mellett bemutatott adataink a terápiás praxis számára is használható tényekre irányítják a figyelmet. A PA személy in vivo körülmények között kiélezett 
figyelmet fordít a menekülési útvonalakra, az útvonalat a megfelelő disztális jelzőingerek hiánya miatt azonban nem tudja a szituáció mentális térképébe hatékonyan beilleszteni. Ennek a sajátos kognitív állapotnak a következménye, hogy a pánikot és agorafóbiát kiváltó szituációban úgymond „elveszti a fejét”, vagyis fejvesztve menekül, miközben a szituáció kontextusát alig képes magáévá tenni. Elveszíti a kontroll lehetőségét a környezete felett, és természetszerủleg gondolja úgy, hogy valami rossz dolog zajlik a környezetében, de csak a saját testén, a saját vegetatív állapotában érzett jelzések azok, amelyeket a zavar forrásaként pontosan be tud azonosítani. Az ebben a helyzetben végzett figyelmi tréning gyakorlatok révén, melyben a figyelem disztális pozitív céltárgyra irányítható, oki terápiás lehetőség kínálkozik a PA megzavart kognitív organizációjának rekonstrukciója számára. Az ilyen biztonsági szignálok felderítése révén módosított figyelmi beállítódás és a kontextuális információ felvételét elősegítő allocentrikus referenciákat aktivizáló gyakorlatok teszik lehetővé a THORPE és SALKOVSKIS (1998) által is leírt kognitív alapzavarok hosszú távú, eredményes rendezését.

\section{IRODALOM}

American Psychiatric Association, Diagnostic and Statistical Manual of Mental Disorders DSM-IVth. Washington, 1994

Andrews, G., Steward, G., Morris-Yates, A., Holt, P., Hendrson, G. (1990) Evidence for a general neurotic syndrome. British Journal of Psychiatry, 157, 6-12.

ARrindell, W. A. (1993) The fear of fear concept: evidence in favor of multidimensionality. Behavior Research and Therapy, 31, 5-18.

Astur, R. S., Koditumakku, J., Dungan, S., Glover, M. L., Ortiz, M. L., Rickert, A., Baca, T., Granado, R. J., Sutherland, R. J. (1998) Place navigation in a virtual Morris water task by normal humans and humans with temporal lobe damage, Soc. Neuroscience Abstract, 621. 8-10.

BARlow, D. H. (1988) Anxiety and its disorders. London, Guilford Press

Beck, A. T. (1978) Depression Inventory. Center for Cognitive Therapy, Philadelphia

Bolles, R. C. (1970) Species specific defense reactions. Psychological Review, 77, 32-48.

Burgess, I. S., Jones, L. M., Robertson, S. A., Radoliffe, W. N., Emerson, E. (1981) The degree of control exerted by phobic and non-phobic verbal stimuli over the recognition behavioural of phobic and non-phobic subjects. Behavioural Research and Therapy, 19, 233-243.

Calvin, W. H. (1991) The Throwing Madonna. Essays on the Brain. Seattle, Washington

Clark, D. M. (1986). A cognitive approach to panic. Behaviour Research and Therapy, 24, $461-470$.

Cornell, E. H., Heth, C. D., Broda, L. S. (1989) Children's wayfinding: Response to instructions to use environmental landmarks, Developmental Psychology, 25, 755-764.

Dabbs, J. M., Chang, E. L., Strong, R. A., Milun, R. (1998) Spatial ability, navigation strategy, and geographic knowledge among men and women. Evolution and Human Behavior, 19, 89-98. 
Easterbrook, J. A. (1959) The effect of emotion on cue utilization and the organization of behavior. Psychological Review, Vol. 6, 3, 183-201.

Ehlers, A., Margraft, J., Davies, S., Roth, W. T. (1988) Selective processing of threat cues in subjects with panic attack. Cognition and Emotion, 2, 201-219.

FOA, G., KOZAK, J. M. (1986) Emotional processing and fear: exposure to corrective information. Psychological Bulletin, 99, 20-35.

Glassman, R. B., Garvey, K. J., Elkins, K. M., Kasal, K. L., Couillard, N. L. (1994) Spatial working memory score of humans in a large radial maze, similar to published score of rats, implies capacity close to the magical number $7 \pm 2$, Brain Research Bulletin, $34,151-159$.

Gorman, J. M. (1987) Panic disorder. In Klein, D. F. (ed.) Modern problems of pharmacopsychiatry. Vol. 22. 36-90. Kargel, Basel

Hibbert, G. A. (1984) Ideational components of anxiety: Their origin and content. British Journal of Psychiatry, 144, 618-624.

Hirtle, S. C., Hudson, J. (1991) Acquisition of spatial knowledge for routes. Journal of Environmental Psychology, 11, 335-345.

Jacobs, W. J., Laurance, H. E., Thomas, K. G. F. (1997) Place learning in virtual space I: Acquisition, overshadowing, and transfer. Learning and Motivation, 28, 521-541.

Jacobs, W. J., NAdel, L. (1985) Stress induced recovery of fears and phobias. Psychological Review, 92, 512-531.

Jacobs, W. J., NADEL, L. (1999a) Neurobiology of reconstructed memory. Psychology of Public Policy and Law, 14, 24-32.

Jacobs, W. J., NAdel, L. (1999b) The first panic attack: A neurobiological theory. Canadian Journal of Psychology, 53, 92-107.

Jacobs, W. J., Thomas, K. G. F., Laurance, H. E., Nadel, L (1998). Place learning in virtual space II: Topographical relations as one dimension of stimulus control. Learning and Motivation, 29, 288-308.

Kagan, J., Rexnick, J. S., Snidman, N., Johnson, M. O., Gibbons, J., Gerstein, M., Biederman, J., Rosenbaum, J. F. (1990) Origins of Panic Disorders. In Ballanger, J. C. (ed.) Neurobiology of Panic Disorder. 71-87. Willey, New York

KÁllai, J. (1989) Attention Fixation Training in panic with agoraphobic patients. Annual meeting of cognitive and behavior therapy ass. Jun. 3-6., Wienna

Kállai, J., Kóczán, Gy., Molnár, P., Szabó, I., VArGa, J. (1995) An experimental study to operationally define and measure spatial orientation in panic agoraphobic subjects. $B e-$ havioural and Cognitive Psychotherapy, 23, 145-152.

Kállai, J., Kosztolányi, P., Osváth, A., Jacobs, W. J. (1999) Cognitive map construction in anxious and control subjects. Journal of Behavior Therapy and Experimental Psychiatry, $26,57-69$

Kállai J., MolnáR P. (1991). A környezetről kialakított kognitív térkép megszerkesztésének hiányosságai agorafóbiás személyeknél. Ideggyógyászati Szemle, 44, 293-302.

VAN DER KOlK, B. A., Fisler, R. (1995) Dissociation and the fragmentary nature of traumatic memory: Overview and exploratory study. Journal of Traumatic Stress, 8, 505-525.

Kopp, M., Foris, N. (1995) Cognitive and behavior therapy of depression. Végeken, Budapest

Kopp, M., Gruzelier, J. (1989). Electrodermally differentiated subgroups of anxiety patients and controls. II. International Journal of Psychophysiology, 7, 65-75. 
LAWTON, C. (1996) Strategies for indoor wayfinding: The role of orientation. Journal of Environmental Psychology, 16, 137-145.

Leckman, J. F., Weissman, M. M., Merikangas, K. R., Pauls, D. L., Prusoff, B. A. (1983) Panic disorder and major depression. Archives General Psychiatry, 40, 1055-1060.

Loftus, E. F., Loftus, G. R., Messo, I. (1987) Some facts about „weapon focus”. Low and Human Behavior, 11, 1-13.

Lupien, S. J., McEwen, B. S. (1997) The acute effects of corticosteroids on cognition. Integration of animal and human model studies. Brain Research Reviews, 24, 1-27.

MaAss, A., Krohnken, G. (1989) Eyewitness identification: Stimulating the „weapon focus.” Law and Human Behavior, 13, 397-408.

MacLeod, C., Rutherford, E. H. (1992) Anxiety and selective processing to emotional information: Mediating roles of awareness trait and state variables, and personal relevance of stimulus materials. Behavior Research and Therapy, 30, 479-491.

Markowitz, J. S., Weissman, M. M., Oullette, R., Lish, J. D., Klerman, G. L. (1989) Quality of life in panic disorder. Arcieves General Psychiatry, 46, 984-992.

Marks, I. M. (1987) Fears, Phobias and Rituals. Oxford Press, Oxford

Mathews, A., Mackintosh, B. (1998) A cognitive model of selective processing in anxiety. Cognitive Therapy and Research, 22, 6, 539-560.

McGaugh, J. L., Introini-Collison, I. B., Cahill, L. F., Castellano, C., Parent, M. B., Williams, C. L. (1993) Neuromodulatory systems and memory storage: Role of the Amigdala. Behavioural Brain Research, 58, 81-90.

McNally, R. J. (1990) Psychological approaches to panic disorder: A review. Psychological Bulletin, 108, 403-419.

MCNally, R. J. (1996) Cognitive bias in the anxiety disorders. In Hope, D. A. (ed.) Perspectives on anxiety, panic and fear. Vol. 43. 211-250. Nebraska Press, Lincoln University, London

Metcalfe, J., Jacobs, W. J. (1996) An interactive hot system/cool system view of memory under stress. PTSD Research Quarterly, 7, 1-6.

Metcalfe, J., Jacobs, W. J. (1998) Emotional memory: The effects of stress on 'cool' and 'hot' memory systems. In Medin, D. L. (ed.), The psychology of learning and motivation: Vol. 38. Advances in research and theory. 187-222. Academic Press, New York

Metcalfe, J., Jacobs, W. J. (1999) Hot emotions under recollection: Modeling memory under stress in CHARM. In Tulving, E. (ed.) Memory, Consciousness, and the Brain: The Tallin Conference. Philadelphia Psychology Press, New York

Nadel, L., Jacobs, W. J. (1996) The role of the hippocampus in PTSD, panic, and phobias. Hippocampus: Functions and Clinical Relevance. 455-463. Elsevier Science B. V., Amsterdam

Nesse, R. M. (1987) An evolutionary perspective on panic disorder and agoraphobia. Ethology and Sociobiology, 8, 73-83.

Noyes, R., Garvey, M. J., Cook, B. L. (1989) Follow-up study of patients with panic disorder and agoraphobia with panic attacks treated with tricyclic antidepressants. Journal of Affective Disorders, 16, 249-257.

Noyes, R., Hoemn-Saric, R. (1998). The Anxiety Disorders. Cambridge University Press, Cambridge

NuUn, J. D., Stevenson, R. J., Whalan, G. (1984) Selective memory effects in agoraphobic patients. British Journal of Clinical Psychology, 23, 195-201. 
O'Keefe, J., Nadel, L. (1978) The Hippocampus as a Cognitive Map. Clarendon Press, Oxford

Overman, W. H., Pate, B. J., Moore, K., Peuster, A. (1996) Ontogeny of place learning in children as measured in the radial arm maze, Morris search task, and open field task. Behavioral Neuroscience, 110, 1205-1228.

Rachman, S. J. (1984) Agoraphobia - as safety signal perspective. Behaviour Research and Therapy, 22, 59-70.

Roth, E. T., Telech, M. J (1986) Autonomic characteristics of agoraphobia with panic attacks. Biological Psychiatry, 21, 1133-1154.

SALKovskis, P. M. (1991) The importance of behaviour of the maintenance of panic and anxiety. Behavioural Psychotherapy, 19, 6-19.

Sandstrom, N. J., Kaufman, J., Huettel, S. A. (1998). Males and females use different distal cues in a virtual environment navigation task. Cognitive Brain Research, 6, 315360

Seigel, A. W., White, S. H. (1975) The development of spatial representations of largescale environments. In Reese, H. W. (ed.) Advances in Child Development. Vol. 10. 37-55. Academic Press, New York

SIPOS, K. (1978) Spielberger STAI - Hungarian version. 14-21. MTA, Budapest

Speilberger, C. D., Gorsuch, R. L., Lushene, R. E. (1970) State-Trait Anxiety Inventory test manual for form $x$. Consulting Psychologists Press, Palo Alto

Thinus-Blanc, C. (1996) Animal Spatial Cognition: Behavioural and Brain Approach. World Scientific Publishing Co., London

Thorpe, S. J., Salkovskis, P. M. (1998) Selective attention to real phobic and safety stimuli. Behaviour Research and Therapy, 36, 471-481.

Watts, F. N. (1989) Attentional strategies and agoraphobic anxiety. Behavioural Psychotherapy, 17, 15-26.

Watts, F. N., McKenna, F. P., Sharock, R., Trezise, L. (1986) Color naming of phobiarelated words. British Journal of Psychology, 77, 97-108.

Williams, J. M. G., Watts, F. N., Macleod, C., Mathews, A. (1988) Cognitive psychology and the emotional disorders. Wiley, Chichester

\section{THE ROLE OF SPATIAL ORIENTATION DISTURBANCES IN MAINTENANCE OF PANIC DISORDER WITH AGORAPHOBIA}

\section{KÁLLAI, JÁNOS-KARÁDI, KÁZMÉR-BICSÁK, ÉVA-KOLLER, ERZSÉBET}

This study compared 15 panic disorder with agoraphobia (PDA), 15 generalized anxiety disorder $(G A D)$, and 15 control female subjects' spatial learning and memory performances with and without stress in Computer Generated Arena place-learning task (C-G Arena) and a real-life labyrinth walk orientation task $(L W)$. PDA subjects compared to GAD and Control subjects showed specific spatial learning and memory deficit under threat relevant situation and in a post-stress spatial learning task. After completing the $L W$ task the PDA subjects frequently missed the route, constructed inaccurate maps and after $L W$ stress were unable to effectively access distal cues. In the C-G Arena task, the PDA 
subjects showed deficits in place learning. The results were interpreted in the context of two models: the Attention Allocation Model and the Stress Induced Recovery (SIR) model.

Key words: $\quad$ cognitive map, spatial disorder, panic, agoraphobia, cue utilization 